Article

\title{
Improving Fusarium Basal Rot Resistance of Onion Cultivars through Artificial Inoculation and Selection of Mature Bulbs
}

\author{
Subhankar Mandal (D) and Christopher S. Cramer* \\ Department of Plant and Environmental Sciences, N127 Skeen Hall, P.O. Box 30003, MSC 3Q, \\ New Mexico State University, Las Cruces, NM 88003-8003, USA; mandals@nmsu.edu \\ * Correspondence: cscramer@nmsu.edu; Tel.: +1-575-646-2657
}

Citation: Mandal, S.; Cramer, C.S. Improving Fusarium Basal Rot Resistance of Onion Cultivars through Artificial Inoculation and Selection of Mature Bulbs. Horticulturae 2021, 7, 168. https:/ / doi.org/10.3390/horticulturae7070168

Academic Editor: Liwang Liu

Received: 12 May 2021

Accepted: 25 June 2021

Published: 29 June 2021

Publisher's Note: MDPI stays neutral with regard to jurisdictional claims in published maps and institutional affiliations.

Copyright: (c) 2021 by the authors. Licensee MDPI, Basel, Switzerland. This article is an open access article distributed under the terms and conditions of the Creative Commons Attribution (CC BY) license (https:/ / creativecommons.org/licenses/by/ $4.0 /)$.

\begin{abstract}
Fusarium basal rot (FBR) of onion, caused by the soil-borne fungus Fusarium oxysporum f.sp. cepae (FOC), results in a substantial storage loss of marketable bulbs. Seedling and field screening methods, which were used to generate FBR resistant long-day and intermediate-day onion cultivars, were found to be ineffective at increasing FBR resistance in short-day onion cultivars. This study attempted to improve the FBR resistance of seven commercial short-day onion cultivars and two check cultivars when evaluated at their mature bulb stage. Mature bulbs were artificially inoculated with $1 \mathrm{~cm}$ diameter potato dextrose agar plugs containing conidia of a virulent FOC isolate, CSC-515, at a concentration of $3 \times 10^{4}$ spore $\mathrm{mL}^{-1}$, after transversely cutting the basal plate tissue. Incubated bulbs, which had few or no FBR symptoms, were selected after $20 \mathrm{~d}$ using visual scoring, from 1 (no disease) to 9 ( $>70 \%$ basal plate is infected), and combined in seed production cages to produce the selected generation of a cultivar. Multiple cycles of phenotypic recurrent selection were conducted, and the resultant populations were compared with their respective original populations for FBR severity and incidence, from 2016 to 2019, using the same conidial inoculation method. A variable amount of progress was achieved in reducing FBR severity and incidence in the seven cultivars, with maximum improvement in the most advanced selected populations. FBR development in the advanced selected populations differed between mature bulbs of each entry and was influenced by yearly environmental variation. The progress of FOC infections was slower in resistant bulbs when compared to susceptible bulbs. These results indicated a partial or quantitative resistance against FBR. The partial FBR resistant cultivar populations could be used to develop synthetic short-day FBR resistant cultivars after multi-locational and multi-seasonal field trials. These populations could also be used to study the mechanism(s) of FBR resistance in onion, which has yet to be determined.
\end{abstract}

Keywords: Fusarium oxysporum f.sp. cepae; disease incidence; disease severity; partial resistance; quantitative resistance

\section{Introduction}

Fusarium basal rot (FBR), which results in a substantial loss of onions around the world, is caused by the soil-borne saprophytic fungus Fusarium oxysporum f.sp. cepae (FOC). Crop rotation with non-host crops and the usage of soil fumigants to counteract FOC has become challenging due to limited land availability, associated cost, and the detrimental effect on beneficial soil microorganisms [1-5]. Therefore, the development of FBR resistant cultivars is a viable alternative to withstand FOC attack in a monocropping system and to circumvent conventional disease control approaches. Even though seedling and field growth stages have been widely used for the selection of disease resistant plants, disease expression in mature bulbs has only been used to evaluate the resistance response [6-11]. Selection during the seedling and the field growing stages would not be effective if dormant FOC causes significant damage during storage under favorable disease development conditions [6]. Selection of FBR resistant germplasm, which depends exclusively on natural field inoculation, has failed to produce significant selection gain $[7,8]$ most likely due to 
nonuniform FOC distribution in evaluation fields [12], resulting in unreliable host-pathogen interactions and, subsequently, disease escape. One primary reason why improving mature bulb FBR resistance was overlooked is due to the absence of any reliable mature bulb screening method other than field screening. To bridge that gap, the onion breeding program at New Mexico State University (NMSU, Las Cruces, NM, USA) has recently developed a conidial inoculation method for mature onion bulbs that produces ample FOC infection in the basal plate tissue of genetically different cultivar populations and eliminates the possibility of any disease escape. This method could replace field screening as a more effective means of selecting FBR resistant onion bulbs [9].

In the past, seedling screening was used heavily to improve FBR resistance in long-day (LD) and intermediate-day onion cultivars $[6,10,13]$. However, to date, no improvement was observed for short-day (SD) cultivars [8]. The transfer of FBR resistance among the different day-length types is restricted due to the day-length specificity of onion to produce marketable bulbs [14]; the variation in isolate virulence in different geographical regions with similar day-lengths [15]; and the high genotype $\mathrm{x}$ isolate interaction to produce variable FBR susceptible phenotypes [16]. Moreover, besides photoperiodic sensitivity and isolate variation, age-related expression of FBR resistance has contributed to a lack of improvement in mature bulb resistance when using a seedling screening for SD cultivars [8,17]. While the molecular basis of resistance against FOC is still unknown in onion, age-dependent expression of Fusarium root rot and Fusarium head blight resistant genes were observed in another monocot, wheat (Triticum aestivum L.) [18]. Even though, FBR disease expression at the seedling and mature bulb stages differs in SD cultivars [8,17], this is not the case for LD cultivars. Studies evaluating moderate to highly FBR resistant LD onion cultivars, such as Ailsa Craig Prizewinner, Hystar, Akgün, and Rossa Savonese, revealed that resistance in the seedling stage was a good indicator of mature bulb FBR resistance $[10,19]$. This difference in resistance profiles between SD and LD cultivars could be attributed to environmental variation, which is known to affect quantitative rather than qualitative resistance traits [20]. Genotype $x$ isolate $x$ day-length interaction was observed to create differing resistance responses to contrasting day-length regimes for a set of standard clones, known to produce non-race-specific quantitative resistance against potato late blight [21]. Since FBR resistance is a quantitative resistance [22] and no specific race was found for this disease, the discrepancy of resistance response between different day-length types could be due to photoperiod, along with age.

Synthetic cultivars with a few known sources of resistance were used extensively in FBR resistance breeding in the past [13], which could be easily overcome through mutation in the pathogen [23]. Therefore, composite cultivars with multiple sources of resistance could provide durable resistance against FBR. Improving commercially available composite cultivars of onion, with the aid of recurrent selection, could save a considerable amount of time. In cross-pollinated crops, recurrent selection has long been used as a valuable tool to improve intrapopulation breeding gains by increasing the frequency of desirable alleles of quantitative trait loci (QTL) via repeated cycles of selection [24]. Multiple economic traits of onion, such as desirable bulb and outer scale characteristics [25], pungency [26], and disease resistance, including FBR and pink root resistance $[6,25,27]$, were improved via this technique. As pink root was reported to be correlated with FBR, with varying susceptibility among New Mexican onion cultivars, we, therefore, hypothesized that the same cultivars should also vary for their FBR susceptibility. Additionally, past field studies involving NMSU onion breeding populations indicated mature bulb FBR severity and incidence were moderately heritable traits [25]. Consequently, our second hypothesis was that under uniform disease pressure created by the conidial inoculation [9], with a few generations of phenotypic recurrent selection, there would be a reduction in the mature bulb FBR severity and incidence of the short-day onion cultivars. This study's objectives were to determine the level of FBR susceptibility of the parent populations of seven New Mexico autumn-sown, Grano-type, short-day onion cultivars and two check cultivars; and 
to assess the improvements in reducing FBR severity and incidence at the mature bulb stage after two cycles of phenotypic recurrent selection using a conidial inoculation.

\section{Materials and Methods}

\subsection{Plant Material}

Seven New Mexico autumn-sown, Grano-type, short-day, open-pollinated onion cultivars were used for this study. The cultivars were NuMex Camino [9,28], NuMex Sweetpak [9,29], NuMex Chaco [9,30], NuMex Mesa [9,31], NuMex Crispy [9,32], NuMex Vado $[9,33]$, and NuMex Luna $[9,33]$. These cultivars are genetically different from each other, except for NuMex Vado and NuMex Luna, which are closely related [9]. These cultivars showed less FBR incidence in field trials [34-36], and are tolerant or resistant to a FBR correlated fungal disease, pink root (Phoma terrestris E.M. Hans.) [6]. Two additional cultivars, NuMex Crimson [37] and Serrana (Monsanto Vegetable Seeds, Woodland, CA, USA) were included in this study as the susceptible and partially resistant checks, respectively, to validate disease development and to compare the FBR susceptibility performance of the selected cultivar populations.

\subsection{Selection of Mature Bulbs for FBR Resistance}

Seeds of the cultivars were grown in raised beds $(5.5 \mathrm{~m} \times 0.56 \mathrm{~m})$, arranged in a randomized complete block design with four replications, starting from September 2015. Standard cultural practices for growing onions in southern New Mexico were followed [34]. Direct seeding was done in two or four rows per bed, and $10 \mathrm{~cm}$ plant-to-plant distance was established at the $4-5$ vegetative leaves stage. Subsurface drip irrigation system (T-Tape; T-Systems International, San Diego, CA, USA) was used at a depth of $10 \mathrm{~cm}$ for irrigation, and to apply fish fertilizer (2 N-3 P-1 K; Neptune's Harvest, Gloucester, MA, USA) and acid-based liquid fertilizer (26 N-0 P-0 K-6 S; Western Blend, Inc., Las Cruces, NM, USA). The crops were overwintered to produce mature bulbs the following summer.

During the summer months (May-August), when the tops of $80 \%$ of the crop were lodged, mature bulbs were harvested and stored in a well-ventilated shed. In the shed, phenotypic recurrent selection was performed to improve FBR resistance of the cultivar populations by artificially inoculating mature bulbs with conidia of the virulent FOC isolate CSC-515. This is one of the local isolates from NMSU Fabian Garcia Science Center that has the ability to separate FBR susceptible and resistant individuals efficiently and was recommended for future screening of FBR resistant germplasm [16]. The detailed methods of conidial inoculation of the FBR resistant populations were published previously [9]. In this study, transversely-cut $(\approx 0.25-0.30 \mathrm{~mm})$ basal plate tissue of mature onion bulbs were inoculated with potato dextrose agar plugs, containing conidia at a concentration of $3.0 \times 10^{4}$ spores $\mathrm{mL}^{-1}$, and kept in high humidity $(\approx 85 \%)$ conditions for $24 \mathrm{~h}$. After an incubation period of 20 days, the basal plates of each bulb were transverselycut $(\approx 0.25-0.30 \mathrm{~mm})$ again to rate for FBR disease development visually. Bulbs rated 9 ( $>70 \%$ of the basal plate was infected) were discarded, and the rest of the bulbs were kept until the end of their storage $[9,38]$.

\subsection{Seed Production and Creating Selected Population}

In the autumn, after the end of storing period (September), bulbs that survived the heavy infestation were massed in a seed production cage $(20 \mathrm{~m}$ length $\times 3 \mathrm{~m}$ width $\times 2 \mathrm{~m}$ height $)$ covered with polyester fabric nets to prevent cross-pollination. During the flowering time in May, when the umbels opened, European honeybees (Apis mellifera L.) and blue bottle flies (Calliphora vomitoria L.) were used for pollination in each cage. Mature umbels were harvested when the seed capsules turned brown. This completed the end of one seed-to-seed cycle. 
With regards to the pedigree of the parental populations and their selections, $\mathrm{C} 0$, or cycle- 0 , was the parental populations of each cultivar and was selected in 2015 to produce two intermediate, or cycle-1, populations, C11 (Cycle-1-Population-1) and C12 (Cycle1-Population-2) (Figure 1). C21 (Cycle-2-Population-1) and C22 (Cycle-2-Population-2) were the two advanced, or cycle-2, populations, selected in 2017 from the C11 and C12 populations, respectively (Figure 1). For the two checks, the $\mathrm{C} 1$, or cycle-1, populations were selected from the C0 populations in 2015.

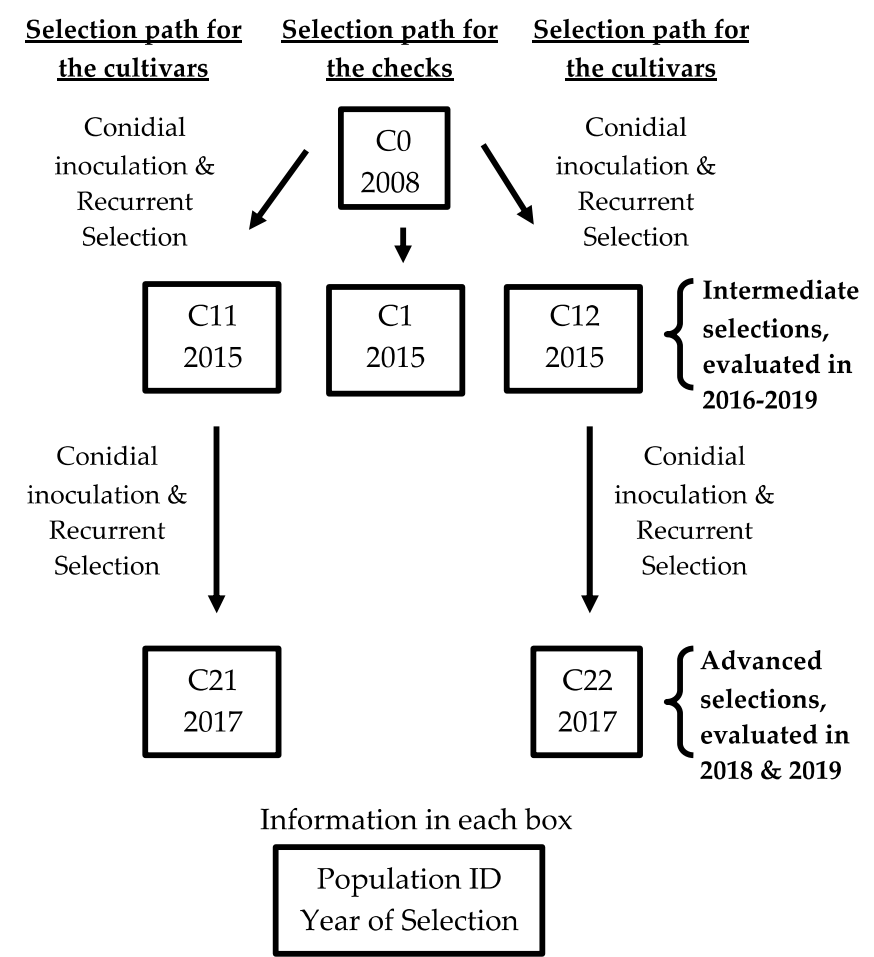

Figure 1. Pedigree showing the selected populations; the method of selection; and the years of selection and evaluation for each cultivar. For this study, C0, or cycle- 0 , was considered as the parent population in each cultivar and the checks. FBR severity and incidence of the $\mathrm{C} 0$ populations were compared to that of the three cycle-1 selected populations, C11 (Cycle-1-Population-1), C12 (Cycle1-Population-2), and C1 (Cycle-1 population for the checks); and two cycle-2 selected populations, C21 (Cycle-2-Population-1), and C22 (Cycle-2-Population-2), which were all originated from the C0 populations after a conidial inoculation.

\subsection{Evaluations of Mature Bulbs for FBR Disease Development}

Seven cultivars, two checks, and their selected populations were evaluated for their FBR resistance during the summer months in New Mexico from 2016 to 2019 (Figure 1). Mature bulbs were grown on raised beds and all the cultural practices were the same as described in the previous sections. After $80 \%$ lodging of the plant tops, bulbs were harvested and stored in a well-ventilated shed for four weeks to allow for any natural FBR development [8]. Non-symptomatic bulbs were evaluated for their FBR resistance by utilizing the conidial inoculation method. Twenty bulbs from each plot were evaluated for FBR severity and incidence by assessing the progress of FBR symptoms in the basal plate tissue and the percentage of inoculated bulbs exhibiting FBR symptoms, respectively [9,38].

\subsection{Statistical Analysis}

The statistical analysis was performed using SAS ${ }^{\circledR}$ Studio in a web-based environment called SAS ${ }^{\circledR}$ OnDemand for Academics (SAS Institute Inc., Cary, NC, USA). Cultivar means of FBR severity and incidence were calculated from mean plot severity and the incidence of twenty bulbs per plot (one replication). Analysis of variance (ANOVA) tests 
were used to compare these cultivar means, as they are used routinely for screening resistance germplasm for biotic and abiotic stresses [39-41]. The assumptions of normality and homogeneity of variance were checked using PROC univariate and PROC GLM hovtest statements (squared residuals, absolute values of residuals, and Brown-Forsythe tests), respectively.

Linear mixed models were constructed for each cultivar and analyzed using a PROC MIXED statement to observe the main and interaction effects of the selected populations, years, and blocks (replications) on the FBR severity and incidence.

$$
\mathrm{y}_{\mathrm{i}(\mathrm{j}) \mathrm{kl}}=\mu_{\mathrm{i}(\mathrm{j})}+\alpha_{\mathrm{i}(\mathrm{j})}+\beta_{\mathrm{i}(\mathrm{j}) \mathrm{k}}+\mathrm{r}_{\mathrm{il}(\mathrm{k})}+\alpha \beta_{\mathrm{i}(\mathrm{j}) \mathrm{k}}+\alpha \mathrm{r}_{\mathrm{i}(\mathrm{j}) \mathrm{l}}+\beta \mathrm{r}_{\mathrm{kl}}+\alpha \beta \mathrm{r}_{\mathrm{i}(\mathrm{j}) \mathrm{kl}}+\mathrm{e}_{\mathrm{i}(\mathrm{j}) \mathrm{kl}}
$$

Here, $\mathrm{y}_{\mathrm{i}(\mathrm{j}) \mathrm{kl}}$ is the mean plot observation of FBR severity or incidence of the ith population of the jth cultivar from the lth block in the kth year; $\mu_{i(j)}$ is the global mean of the ith cultivar population nested within the jth cultivar; $\alpha_{i(j)}$ is the effect of the ith population of the jth cultivar; $\beta_{i(j) k}$ is the effect of the ith cultivar population in the kth year; $\mathrm{r}_{\mathrm{il}(\mathrm{k})}$ is the effect of the ith cultivar population in the lth replicate nested within the kth year; $\alpha \beta_{i(j) k}$ is the interaction effect of the ith population of the jth cultivar in the kth year; $\alpha r_{i(j) l}$ is the interaction effect of the ith population of the jth cultivar in the lth replication; $\beta r_{\mathrm{kl}}$ is the interaction effect of the kth year and lth replication; $\alpha \beta \mathrm{r}_{\mathrm{i}(j) \mathrm{kl}}$ is the interaction effect of the ith population of the jth cultivar in kth year and lth replication; and $\mathrm{e}_{\mathrm{i}(\mathrm{j}) \mathrm{kl}}$ is the unexplained or residual error. In the mixed models, population, year and their interaction were considered as fixed effects, while the rest of the terms were considered as random effects. Pair-wise comparisons with contrast statement were made to assess the improvement of reducing FBR severity and incidence of the selected populations.

\section{Results}

\subsection{Sources of Variance}

Cultivar populations varied significantly in FBR severity and incidence, suggesting that selections created more variations for the parameters in some cultivars than the others (Supplementary Tables S1-S3). Significant year and year $\times$ population interactions for FBR severity and incidence indicated that the two parameters were equally influenced by environmental factors.

\subsection{New Mexico Short-Day Cultivars Varied in Mature Bulb FBR Susceptibility}

The variable mean annual FBR severities and incidences were obtained for the parental or $\mathrm{C} 0$ populations, with the lowest ones recorded for NuMex Camino with 5.6 and $65.4 \%$, respectively (Figure 2a and Supplementary Figure S1). NuMex Vado (mean annual severity of 7.8 and incidence of $87.9 \%$ ) and NuMex Luna (mean annual severity of 8.6 and incidence of $96.5 \%$ ) C0 populations were found to be very susceptible, similar to the susceptible check, NuMex Crimson (Figure 2b and Supplementary Figure S1).

\subsection{Lower FBR Severity and Incidence Observed for Selected Populations}

A variable amount of progress was realized for improving FBR resistance of the intermediate and the advanced selected populations of the checks and the seven cultivars (Figure 2 and Supplementary Figure S1). The reductions of the mean annual FBR severity for NuMex Crimson and Serrana were $37.5 \%$ and $30.7 \%$, respectively (Figure $2 b$ ). Greater improvement was observed in the advanced selected populations of NuMex Sweetpak, NuMex Chaco, NuMex Crispy, and NuMex Vado (Figure 2a). For instance, mean annual FBR severities of the NuMex Vado C11 and C21 populations were $18.7 \%$ and $48.3 \%$ lower, respectively, compared to that of the $\mathrm{C} 0$ population (Figure 2a). Even though severity and incidence were correlated in most of the cases in the present study (Figure 2 and Supplementary Figure S1), several C21 and C22 populations of NuMex Sweetpak, NuMex Chaco, NuMex Crispy, and NuMex Vado exhibited a lower FBR severity than the susceptible NuMex Crimson population, but higher disease incidences than its selected population C1, which showed the least FBR severity in our trials (Figure 3). 

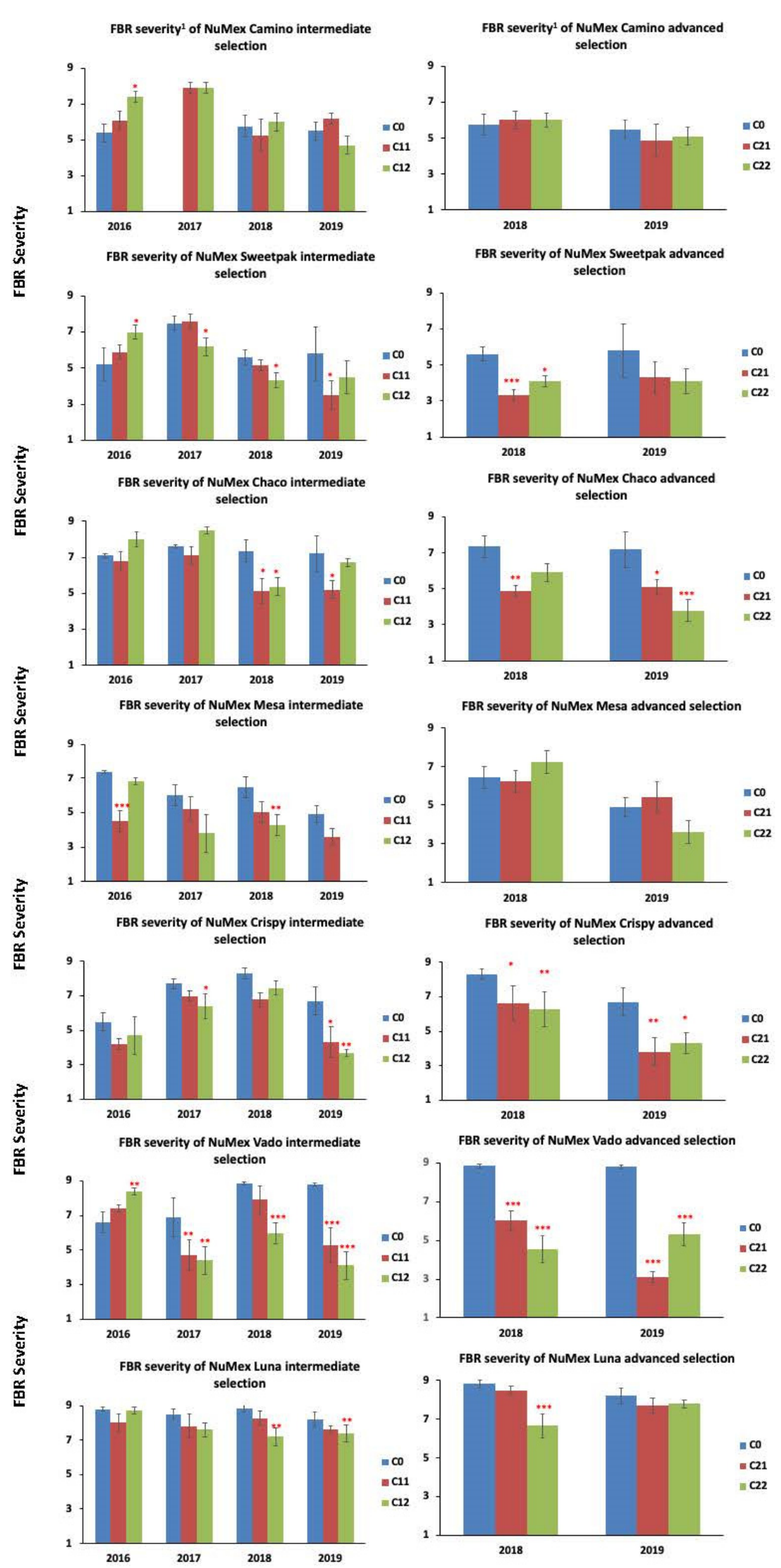

(a)

Figure 2. Cont. 

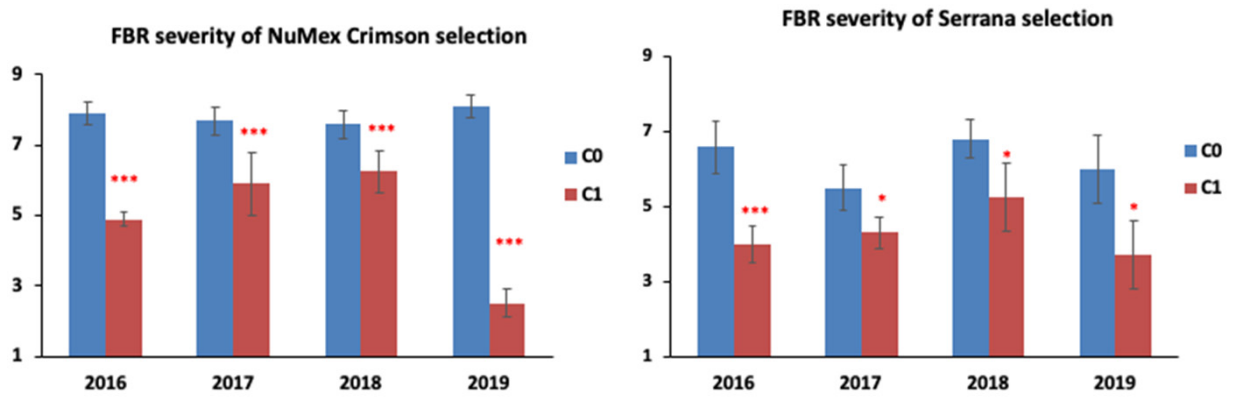

(b)

Figure 2. FBR severity of the (a) seven cultivars and (b) two checks, comprising the parental or C0 populations with their first cycle of selected populations, C1, C11, and C12, and second cycle of selected populations, C21 and C22, evaluated for four and two seasons, respectively. ${ }^{1}$ FBR severity was calculated after $20 \mathrm{~d}$ of incubation. Twenty randomly selected FOC-inoculated bulbs were rated individually for FBR severity on a scale of 1 to $9(1=$ no symptoms; $9>70 \%$ of the basal plate is infected). Error bars are the standard errors of the mean FBR severities of each cultivar population. ${ }^{*}, * *{ }^{* * *}$ significantly different from C0 at $p<0.05,0.01$, and 0.001 , respectively, in each year.

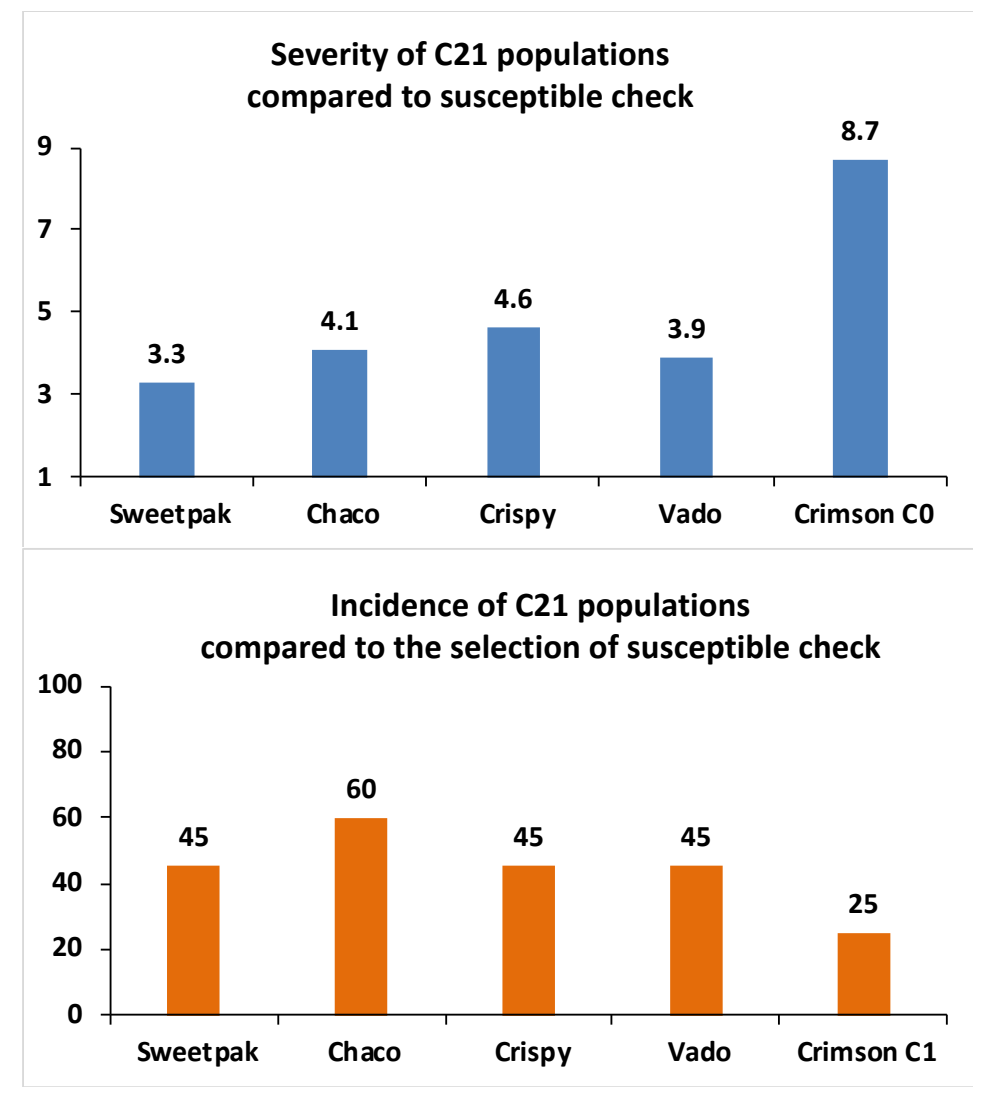

Figure 3. Partial FBR resistance of the C21 populations of four cultivars, NuMex Sweetpak, NuMex Chaco, NuMex Crispy, and NuMex Vado, characterized by lower FBR severity than susceptible check population, NuMex Crimson C0, and higher FBR incidence than the selection, NuMex Crimson C1, in the 2019 season.

Apart from interpopulation variance, intrapopulation variance in FBR severity and incidence was also observed for the selected populations. For example, standard deviations of the NuMex Crispy C21 population were 2.07 (2018) and 1.61 (2019) (Figure 4a); and that of the NuMex Vado C21 population were 1.12 (2018) and 0.56 (2019) (Figure 4b). 


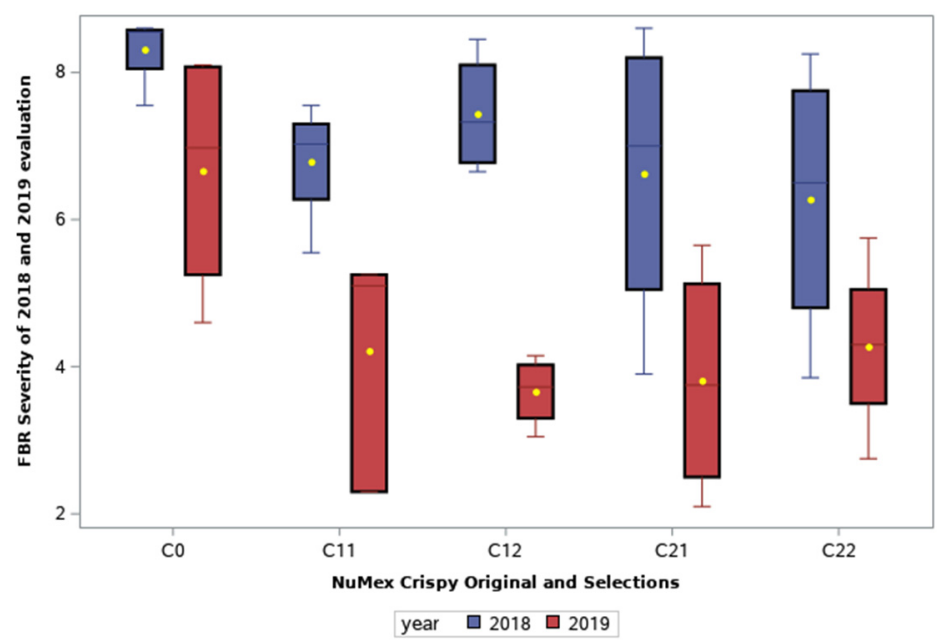

(a)

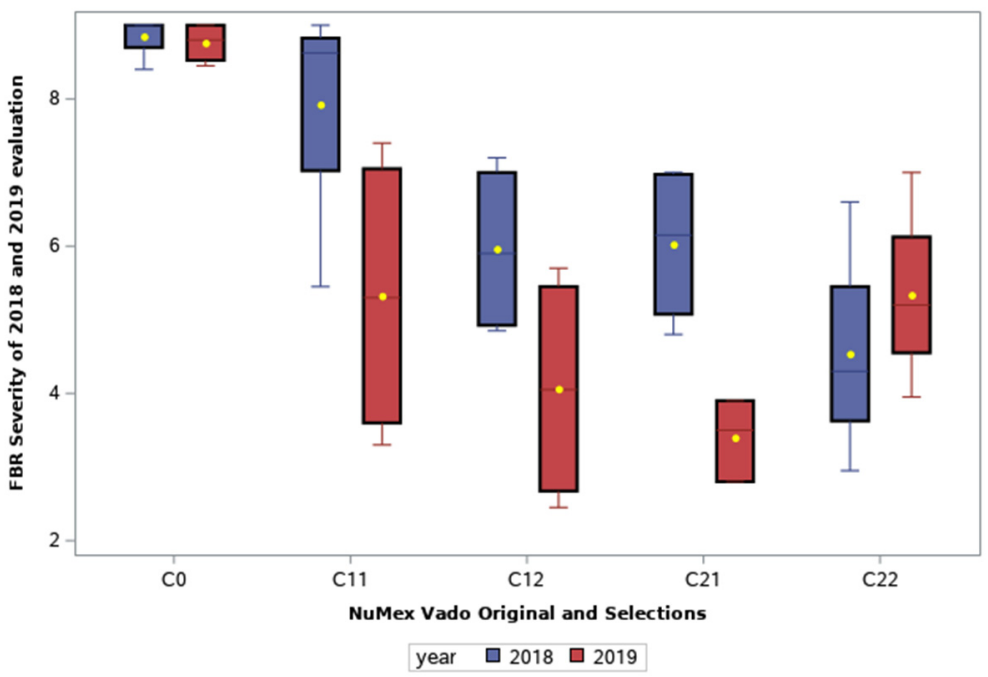

(b)

Figure 4. Box plots showing intrapopulation variance of FBR severity as a result of selection in (a) NuMex Crispy and (b) NuMex Vado. Each entry was tested in a randomized complete block design with four replications. A mean population FBR severity, which is indicated by a yellow dot, was calculated over eighty bulbs, i.e., twenty per replication. Each boxplot is divided equally into four groups, viz., upper and lower whiskers (comprising the highest and lowest 25\% severities); and upper and lower quartiles (comprising the middle 50\% and median severities).

\section{Discussion}

\subsection{FBR Susceptibility of the New Mexico Short-Day Onion Cultivars and Their Selections}

Original populations of the seven onion cultivars demonstrated medium to high mature bulb FBR severity and incidence compared to the susceptible check that coincides partially with their field performances during past evaluations. As an example, NuMex Mesa exhibited less FBR susceptibility than either NuMex Vado or NuMex Luna (Figure 2a) [42-44]. Genetic differences of the cultivar's FBR susceptibility originated from their multiple parents during development, and could not reflect properly when plants were evaluated directly in the field due to the uneven field distribution of the FOC isolates, microbial antagonism, suppressive soils formation, and the lower amount of FOC isolates in natural conditions $[8,12,45]$. In contrast, differential expressions of inherent FBR resistance were possible via a conidial inoculation method due to initial high humidity and removal of the outer basal plate layer, which mimics the natural inoculation conditions of 
an extensive period of wet soil during excessive rainfall [46] and natural wounds or cracks formed due to bulb growth expansion or abiotic stress [9], respectively.

A lower FBR susceptibility after a single cycle of selection, as observed for the two checks, demonstrated the superiority of the conidial inoculation over field inoculation $[7,8]$ to improve FBR resistance in mature bulbs. This improvement in FBR resistance was expected as this trait is heritable and responded well to recurrent selection in the past [25]. Lesser FBR severity and lower incidence with successive generations of selection was an indication of additive inheritance of the major and minor genes, which confers quantitative FBR resistance in cultivated onion [8,17,47-50]. Expression of the genes depends upon the stage of plant growth $[8,17,50]$, genetic backgrounds of cultivars or inbreeds $[48,49,51]$, and environmental variation [50], which cumulatively explained the yearly variation of FBR severity and incidence observed in the present and past variety trials [25,38]. With successive selection cycles, we expected to reduce the intrapopulation variability of the resistant lines, which is inevitably due to the high outcrossing nature of this crop, resulting in a variable distribution of the resistance genes among the individuals in a population [52].

\subsection{FBR Resistance Is Partial or Quantitative in Nature}

In this study, FBR severity and incidence were both found to be major factors of resistance against FOC and were highly correlated (Figure 2 and Supplementary Figure S1). Incidence of vascular wilt pathogens, like Fusarium, is largely modulated by physical defense restricting its spread to xylem vessels [53]. This was demonstrated in onion when intact dry outer basal plate tissue of mature bulbs resulted in minimal infection upon artificial inoculation [9]. Once the physical defense was breached, a chemical defense was initiated to inhibit pathogen growth in the xylem vessels [53], which could explain the slower disease progression in the advanced selected C21 populations of NuMex Sweetpak, NuMex Chaco, NuMex Crispy, and NuMex Vado (Figure 3), as also observed in earlier studies [6]. Slowing the rate of disease progression is a characteristic symptom of partial, incomplete or horizontal resistance, and a result of multiple factors acting quantitatively [54]. Identification of seven homologs of Fusarium oxysporum f.sp. lycopersici, secreted in Xylem sap (SIX) genes, code for pathogenic effector proteins in FOC [55], indicating that the defense response of onion against FOC should be effector-triggered immunity, which results in an array of proteins and metabolic changes in xylem [53]. Upregulation of the pathogenesis-related (PR) protein genes, which provide the basal defense against Fusarium, is triggered by the early signaling of salicylic acid, calcium ions, and phosphatidic acids, followed by systematic expression of the defense genes induced by jasmonic acid and ethylene signaling $[53,56]$. Omics analyses revealed the production of phytoalexins, mycotoxin detoxification enzymes, cell wall fortification, and programmed cell death by reactive-oxygen species (ROS) as some of the other ways plants work to contain the vertical and lateral growth of Fusarium pathogens inside xylem vessels [53,56]. In a recent study of shallot (Allium cepa L. var. aggregatum G. Don), a closely related Allium of cultivated onion, steroidal saponins, alliospiroside $A$ and alliospiroside $B$, were shown to be the primary method of protection against soil-borne fungi by causing mitochondrial membrane damage using ROS [57]. A follow-up study revealed the role of cytochrome P450, UDPglucosyltransferases, and beta-glucosidase protein encoding genes in FBR defense [58]. Different amounts and distribution of these resistance genes and their alleles in the cultivar populations could explain the non-race specific, quantitative, and environmentally influenced resistance against FBR, similar to Fusarium head blight (FHB) resistance of wheat (Triticum aestivum L.) (Supplementary Tables S1-S3, Figure 2, and Supplementary Figure S1) [16,59]. As observed for FHB, a high correlation between FBR severity and incidence also indicates that the resistance genes for the two parameters could overlap to confer resistance against FOC, as a single FBR resistant QTL could produce multiple resistance expressions [59].

Even though the genotypic effect of FBR resistance QTLs is still unknown [22], the impact of selection could be equally predicted by the moderate heritability of this pheno- 
type among the NMSU lines [25,60]. The lack of improvement in FBR resistance for the NuMex Camino, NuMex Mesa, and NuMex Luna selected populations (Figure 2a and Supplementary Figure S1) could be due to small changes in gene frequency that result in slower gain per selection $[61,62]$. One apparent reason for the lack of progress is a lower frequency of desired alleles in the parental populations, which could be fixed for FBR resistant gene(s) when selected for the correlated fungal disease, pink root [6]. Secondly, no visible phenotypic effect would be realized if the genes under selection were outweighed by a different set of genes with lower frequencies in the parent population [62], as indicated by the large intrapopulation variance in the selected cultivar populations (Figure 4). A complete understanding of the FBR resistance in onion is needed to compare FBR resistant QTL [22] functionalities with approaches of genomics, transcriptomics, metabolomics, and proteomics [59]. The cultivar populations from this study, which differed considerably in their FBR resistance phenotypes, could be valuable material in that aspect. Furthermore, due to the additive nature of FBR resistance, initial phenotypic recurrent selection could facilitate marker-assisted selection by intensifying resistant alleles in the major loci [63].

\section{Conclusions and Future Breeding}

Seven short-day, Grano-type, New Mexican onion cultivars were evaluated after multiple cycles of phenotypic recurrent selection using conidial inoculation to improve FBR resistance in the mature bulb stage. Selected populations varied in their mature bulb severity and incidence with a greater improvement occurring in the advanced selected populations of four cultivars, which indicated an additive inheritance of the FBR resistance genes. The seasonal environmental variations for FBR severity and incidence, and a slower rate of disease progression, in the FBR resistant population's basal plate indicated partial or quantitative resistance against FBR. Conversely, cultivars with no improvement for FBR resistance might indicate lower abundance or fixation of the desired alleles in the parental population during their developmental process. Cultivar populations with partial resistance developed in this study could be evaluated in multi-locational and multi-seasonal field trials to validate their potential in short-day FBR resistant cultivar development. Moreover, the most resistant cultivar breeding lines could be used to study the mechanism(s) of FBR resistance and to facilitate marker-assisted selection.

Supplementary Materials: The following are available online at https:/ /www.mdpi.com/article/10 .3390 /horticulturae7070168/s1, Table S1: the fixed effect ANOVA of FBR severity and incidence of early maturing cultivars comprising the original, intermediate, and advanced selected populations evaluated for four seasons; Table S2: the fixed effect ANOVA of FBR severity and incidence of intermediate maturing cultivars comprising of the original, intermediate, and advanced selected populations evaluated for four seasons; Table S3: the fixed effect ANOVA of FBR severity and incidence of late maturing cultivars comprising the original, intermediate, and advanced selected populations evaluated for four seasons; Figure S1: FBR incidence of the seven cultivars and two checks, comprising the parental, or $\mathrm{C} 0$, populations with their first cycle of selected populations, $\mathrm{C} 1$, $\mathrm{C} 11$, and C12, and second cycle of selected populations, C21 and C22, evaluated for four and two seasons, respectively.

Author Contributions: Investigation, methodology, data curation, formal analysis, visualization, writing-original draft preparation, conceptualization, supervision, investigation, methodology, writing-review and editing, S.M. and C.S.C. Both authors have read and agreed to the published version of the manuscript.

Funding: The authors would like to thank the New Mexico Agricultural Experiment Station for their funding support in this study.

Institutional Review Board Statement: Not applicable.

Informed Consent Statement: Not applicable.

Data Availability Statement: The data presented in this study are available upon request from the corresponding author. The data are not publicly available due to privacy concerns. 
Acknowledgments: The authors would like to thank Nicholas Santantonio, Brock Blaser, Allison Walker and Dennis Nicuh Lozada for their valuable reviews to improve the quality and contents of the manuscript. The authors would also like to thank Ray Muhyi and the undergraduate students for their assistance in managing plants in the greenhouse and the field.

Conflicts of Interest: The authors declare no conflict of interest.

\section{References}

1. Bennett, A.J.; Bending, G.D.; Chandler, D.; Hilton, S.; Mills, P. Meeting the demand for crop production: The challenge of yield decline in crops grown in short rotations. Biol. Rev. 2012, 87, 52-71. [CrossRef]

2. Sumner, D.R. Fusarium basal rot. In Compendium of Onion and Garlic Diseases; Schwartz, H.F., Mohan, S.K., Eds.; The American Phytopathological Society (APS): St. Paul, MN, USA, 1995; pp. 10-11.

3. Thornton, M.K.; Mohan, S.K. Response of sweet spanish onion cultivars to basal rot and pink root. Plant Dis. 1996, 80, 660-663. [CrossRef]

4. Brown, B.D. Onion response to fumigation and P placement. Onion World 2001, 17, 8-9.

5. Jawson, M.D.; Franzluebbers, A.J.; Galusha, D.K.; Aiken, R.M. Soil fumigation within monoculture and rotations: Response of corn and mycorrhizae. Agron. J. 1993, 85, 1174-1180. [CrossRef]

6. Cramer, C.S. Breeding and genetics of Fusarium basal rot resistance in onion. Euphytica 2000, 115, 159-166. [CrossRef]

7. Caligiore-Gei, P.F.; Ciotti, M.L.; Valdez, J.G.; Galmarini, C.R. Breeding onion for resistance to Fusarium basal rot: Comparison of field selection and artificial inoculation. Trop. Plant Pathol. 2020. [CrossRef]

8. Mandal, S.; Saxena, A.; Cramer, C.S.; Steiner, R.L. Comparing efficiencies of two selection approaches for improving Fusarium Basal Rot resistance in short-day onion after a single cycle of selection. Horticulturae 2020, 6, 26. [CrossRef]

9. Mandal, S.; Cramer, C.S. An artificial inoculation method to select mature onion bulbs resistant to Fusarium basal rot. HortScience 2020, 55, 1840-1847. [CrossRef]

10. Taylor, A.; Vagany, V.; Barbara, D.J.; Thomas, B.; Pink, D.A.C.; Jones, J.E.; Clarkson, J.P. Identification of differential resistance to six Fusarium oxysporum $\mathrm{f}$. sp. cepae isolates in commercial onion cultivars through the development of a rapid seedling assay. Plant Pathol. 2013, 62, 103-111. [CrossRef]

11. Rout, E.; Tripathy, P.; Nanda, S.; Nayak, S.; Joshi, R.K. Evaluation of cultivated and wild allium accessions for resistance to Fusarium oxysporum f. sp. cepae. Proc. Natl. Acad. Sci. India Sect. B Biol. Sci. 2016, 86, 643-649. [CrossRef]

12. Saxena, A. Screening of Onion Cultivars for Fusarium Basal Rot and Spatial Distribution of Fusarium oxysporum f.sp. cepae. Master's Thesis, New Mexico State University, Las Cruces, NM, USA, 2007.

13. Marzu, J.C. Genetic Analyses of Resistances to Fusarium Basal Rot and Pink Root in Onion. Ph.D. Thesis, University of WisconsinMadison, Madison, WI, USA, 2015.

14. Jones, H.A.; Mann, L.K. Onion and Their Allies; Leonard Hill (Books) Limited: London, UK, 1963.

15. Caligiore-Gei, P.F.; Valdez, J.G.; Piccolo, R.J.; Galmarini, C.R. Influence of Fusarium spp. isolate and inoculum density on resistance screening tests in onion. Trop. Plant Pathol. 2014, 39, 19-27. [CrossRef]

16. Saxena, A.; Cramer, C.S. Screening of Onion Seedlings for Resistance against New Mexico Isolates of Fusarium oxysporum f. sp. cepae. J. Plant Pathol. 2009, 91, 199-202.

17. Holz, G.; Knox-Davies, P.S. Resistance of onion selections to Fusarium oxysporum f sp cepae. Phytophylactica 1969, 1, 153-156.

18. Wang, Q.; Shao, B.; Shaikh, F.I.; Friedt, W.; Gottwald, S. Wheat resistances to fusarium root rot and head blight are both associated with deoxynivalenol- and jasmonate-related gene expression. Phytopathology 2018, 108, 602-616. [CrossRef] [PubMed]

19. Özer, N.; Köycü, N.D.; Chilosi, G.; Magro, P. Resistance to fusarium basal rot of onion in greenhouse and field and associated expression of antifungal compounds. Phytoparasitica 2004, 32, 388-394. [CrossRef]

20. Yang, Q.; Balint-Kurti, P.; Xu, M. Quantitative disease resistance: Dissection and adoption in maize. Mol. Plant. 2017, 10, 402-413. [CrossRef]

21. Mihovilovich, E.; Munive, S.; Bonierbale, M. Influence of day-length and isolates of Phytophthora infestans on field resistance to late blight of potato. Theor. Appl. Genet. 2010, 120, 1265-1278. [CrossRef] [PubMed]

22. Taylor, A.; Teakle, G.R.; Walley, P.G.; Finch-Savage, W.E.; Jackson, A.C.; Jones, J.E.; Hand, P.; Thomas, B.; Havey, M.J.; Pink, D.A.; et al. Assembly and characterisation of a unique onion diversity set identifies resistance to Fusarium basal rot and improved seedling vigour. Theor. Appl. Genet. 2019, 132, 3245-3264. [CrossRef]

23. van de Wouw, A.P.; Cozijnsen, A.J.; Hane, J.K.; Brunner, P.C.; McDonald, B.A.; Oliver, R.P.; Howlett, B.J. Evolution of linked avirulence effectors in Leptosphaeria maculans is affected by genomic environment and exposure to resistance genes in host plants. PLoS Pathog. 2010, 6, e1001180. [CrossRef] [PubMed]

24. Hallauer, A.R. Compendium of recurrent selection methods and their application. CRC Crit. Rev. Plant Sci. 1985, 3, 1-33. [CrossRef]

25. Cramer, C.S. Onion trait heritability and response from selection. J. Am. Soc. Hortic. Sci. 2006, 131, 646-650. [CrossRef]

26. Yoo, K.S.; Pike, L.M.; Patil, B.S.; Lee, E.J. Developing sweet onions by recurrent selection in a short-day onion breeding program. Sci. Hortic. 2020, 266, 109269. [CrossRef]

27. Yamashita, K.I.; Wako, T.; Ohara, T.; Tsukazaki, H.; Kojima, A. Improvement of rust resistance in bunching onion (Allium fistulosum L.) by recurrent selection. J. Jpn. Soc. Hortic. Sci. 2005, 74, 444-450. [CrossRef] 
28. Cramer, C.S.; Corgan, J.N. “NuMex Camino" Onion. HortScience 2003, 38, 1251-1252. [CrossRef]

29. Wall, M.; Corgan, J. “NuMex Sweetpak” onion. HortScience 1999, 34, 1303-1304. [CrossRef]

30. Cramer, C.S.; Corgan, J.N. “Numex Chaco" onion. HortScience 2001, 38, 1337-1338. [CrossRef]

31. Plant Variety Protection Certificate of 'NuMex Mesa', PVPO No. 9600351, United States Department of Agriculture. 1996. Available online: https: / apps.ams.usda.gov/CMS/ (accessed on 26 June 2021).

32. Plant Variety Protection Certificate of 'NuMex Crispy', PVPO No. 9600348, United States Department of Agriculture. 1996. Available online: https:/ / apps.ams.usda.gov/CMS/ (accessed on 26 June 2021).

33. Plant Variety Protection Certificates of 'NuMex Luna' (PVPO No. 9600350) and 'NuMex Vado' (PVPO No. 9600352), United States Department of Agriculture. 1996. Available online: https:/ /apps.ams.usda.gov/CMS/ (accessed on 26 June 2021).

34. Walker, S.; Ashigh, J.; Cramer, C.; Sammis, T.; Lewis, B. Bulb Onion Culture and Management for Southern New Mexico; Cooperative Extension Service Circular 563; New Mexico State University, Agricultural Experiment Station: Las Cruces, NM, USA, 2009.

35. Lopez, J.A.; Cramer, C.S. Screening intermediate-day onion lines for fusarium basal rot resistance. In Proceedings of the National Onion Research Conference, Pasco, WA, USA, 11-14 December 2002; pp. 82-86.

36. Lopez, J.A.; Cramer, C.S. Screening Short-Day Onion Varieties for Resistance to Fusarium Basal Rot. Acta Hortic. 2004, 637, 169-173. [CrossRef]

37. Cramer, C.S.; Corgan, J.N. “NuMex Crimson” onion. HortScience 2003, 38, 306-307. [CrossRef]

38. Gutierrez, J.A.; Cramer, C.S. Screening short-day onion cultivars for resistance to fusarium basal rot. HortScience 2005, 40, 157-160. [CrossRef]

39. Monroy-Barbosa, A.; Bosland, P.W. A rapid technique for multiple-race disease screening of Phytophthora foliar blight on single Capsicum annuum L. plants. HortScience 2010, 45, 1563-1566. [CrossRef]

40. Bankole, F.; Menkir, A.; Olaoye, G.; Crossa, J.; Hearne, S.; Unachukwu, N.; Gedil, M. Genetic gains in yield and yield related traits under drought stress and favorable environments in a maize population improved using marker assisted recurrent selection. Front. Plant Sci. 2017, 8, 808. [CrossRef] [PubMed]

41. Strange, E.B.; Guner, N.; Pesic-VanEsbroeckb, Z.; Wehner, T.C. Screening the watermelon germplasm collection for resistance to papaya ringspot virus type-W. Crop Sci. 2002, 42, 1324-1330. [CrossRef]

42. Cramer, C.S.; Muhyi, R.I. 2001-2002 Onion variety trials at New Mexico State University. In Proceedings of the National Allium Research Conference, Pasco, WA, USA, 11-14 December 2002; pp. 23-33.

43. Cramer, C.S.; Corgan, J.N.; Mendoza, J.L.; Wall, M.M. 1999-2000 Onion Variety Trials at New Mexico State University; New Mexico State University, Agricultural Experiment Station: Las Cruces, NM, USA, 2001; p. 38.

44. Cramer, C.S.; Mendoza, J.L.; Wall, M.M. 2000-2001 Onion Variety Trials at New Mexico State University; New Mexico State University, Agricultural Experiment Station: Las Cruces, NM, USA, 2002; p. 748.

45. Abawi, G.S.; Lorbeer, J.W. Populations of Fusarium oxysporum f. sp. cepae in organic soils in New York. Phytopathology 1971, 61, 1042-1048. [CrossRef]

46. Shock, C.C.; Feibert, E.B.G.; Saunders, L.D. Onion yield and quality affected by soil water potential as irrigation threshold. HortScience 1998, 33, 1188-1191. [CrossRef]

47. Bacher, J.W.; Pan, S.; Ewart, L. Inheritance of Resistance to Fusarium oxysporum f. sp. cepae in Cultivated Onions; Jensen, L., Ed.; Michigan State University: East Lansing, MI, USA, 1989; pp. 85-91.

48. Kehr, A.E.; O'Brien, M.J.; Davis, E.W. Pathogenicity of Fusarium oxysporum f. sp. cepae and its interaction with Pyrenochaeta terrestris on onion. Euphytica 1962, 11, 197-208. [CrossRef]

49. Lorbeer, J.W.; Stone, K.W. Reaction of onion to Fusarium basal rot. Plant Dis. Rep. 1965, 49, 522-526.

50. Tsutsui, K. Inheritance of resistance to Fusarium Basal Rot. Master's Thesis, University of Wisconsin-Madison, Madison, WI, USA, 1991.

51. Krueger, S.K.; Weinman, A.A.; Gabelman, W.H. Combining ability among inbred onions for resistance to Fusarium basal rot. HortScience 1989, 24, 1021-1023.

52. Loveless, M.D.; Hamrick, J.L. Ecological determinants of genetic structure in plant populations. Annu. Rev. Ecol. Syst. 1984, 15, 65-95. [CrossRef]

53. Yadeta, K.; Thomma, B. The xylem as battleground for plant hosts and vascular wilt pathogens. Front. Plant Sci. 2013, 4, 97. [CrossRef] [PubMed]

54. Parlevliet, J.E.; Zadoks, J.C. The integrated concept of disease resistance: A new view including horizontal and vertical resistance in plants. Euphytica 1977, 26, 5-21. [CrossRef]

55. Armitage, A.D.; Taylor, A.; Sobczyk, M.K.; Baxter, L.; Greenfield, B.P.; Bates, H.J.; Wilson, F.; Jackson, A.C.; Ott, S.; Harrison, R.J.; et al. Characterisation of pathogen-specific regions and novel effector candidates in Fusarium oxysporum f. sp. cepae. Sci. Rep. 2018, 8, 1-15. [CrossRef]

56. Ma, Z.; Xie, Q.; Li, G.; Jia, H.; Zhou, J.; Kong, Z.; Li, N.; Yuan, Y. Germplasms, genetics and genomics for better control of disastrous wheat Fusarium head blight. Theor. Appl. Genet. 2020, 133, 1541-1568. [CrossRef] [PubMed]

57. Teshima, Y.; Ikeda, T.; Imada, K.; Sasaki, K.; El-Sayed, M.A.; Shigyo, M.; Tanaka, S.; Ito, S.I. Identification and biological activity of antifungal saponins from shallot (Allium cepa L. Aggregatum Group). J. Agric. Food Chem. 2013, 61, 7440-7445. [CrossRef] [PubMed] 
58. Abdelrahman, M.; El-Sayed, M.; Sato, S.; Hirakawa, H.; Ito, S.I.; Tanaka, K.; Mine, Y.; Sugiyama, N.; Suzuki, M.; Yamauchi, N.; et al. RNA-sequencing-based transcriptome and biochemical analyses of steroidal saponin pathway in a complete set of Allium fistulosum-A. cepa monosomic addition lines. PLoS ONE 2017, 12, e0181784. [CrossRef] [PubMed]

59. Ghimire., B.; Sapkota, S.; Bahri, B.A.; Martinez-Espinoza, A.D.; Buck, J.W.; Mergoum, M. Fusarium Head Blight and Rust Diseases in Soft Red Winter Wheat in the Southeast United States: State of the Art, Challenges. Front. Plant Sci. 2020, 11, 1080. [CrossRef] [PubMed]

60. Paterson, A.H.; Damon, S.; Hewitt, J.D.; Zamir, D.; Rabinowitch, H.D.; Loncoln, S.E.; Lander, E.S.; Tanksley, S.D. Mendelian factors underlying quantitative traits in tomato: Comparison across species, generations, and environments. Genetics 1991, 127, 181-197. [CrossRef]

61. Dweba, C.C.; Figlan, S.; Shimelis, H.A.; Motaung, T.E.; Sydenham, S.; Mwadzingeni, L.; Tsilo, T.J. Fusarium head blight of wheat: Pathogenesis and control strategies. Crop Prot. 2017, 91, 114-122. [CrossRef]

62. Hill, W.G. Understanding and using quantitative genetic variation. Philos. Trans. R. Soc. B Biol. Sci. 2010, 365, 73-85. [CrossRef]

63. Agostinelli, A.M.; Clark, A.J.; Brown-Guedira, G.; Van Sanford, D.A. Optimizing phenotypic and genotypic selection for Fusarium head blight resistance in wheat. Euphytica 2012, 186, 115-126. [CrossRef] 